\title{
Immunocytochemical Identification of Primary Olfactory Afferents in Rainbow Trout
}

\author{
DAVID R. RIDDLE AND BRUCE OAKLEY \\ Neuroscience Program and Department of Biology, The University of Michigan, Ann Arbor, \\ Michigan 48109
}

\begin{abstract}
We have used a combination of techniques to analyze the primary olfactory projection in trout: anterograde tract tracing with horseradish peroxidase (HRP) and immunocytochemistry with antisera to olfactory marker protein (OMP) and to keyhole limpet hemocyanin (KLH). HRP labeling and the OMP antiserum revealed a subset of ciliated receptor neurons with a wide dendrite that lacked the protruding knob found on other receptor neurons. The organization of the primary olfactory axons was clearly revealed by antisera to KLH, which reacted with no other neurons. When visualized with anti-KLH, fascicles of olfactory axons penetrated the basal lamina of the olfactory rosette at scattered sites and converged to form the olfactory nerve. Fascicles within the olfactory nerve traveled parallel to the long axis of the nerve until resorted by extensive intermixing as they entered the olfactory bulb. Within the olfactory bulb, most axons terminated in nine discrete terminal fields in the glomerular layer; however, a few olfactory nerve axons projected into the ventral medial telencephalon. Fascicles supplying each terminal field in the glomerular layer followed distinctive trajectories within the olfactory nerve layer. Axons ending in two terminal fields made brush-like terminations rather than the glomerular terminations characteristic of the remaining seven fields. After unilateral olfactory nerve transection, returning olfactory axons reestablished the normal pattern of terminal fields within 14 weeks. It is likely that the organization of afferents in the trout olfactory bulb is similarly well regulated during normal receptor cell replacement. 1992 Wiley-Liss, Inc.
\end{abstract}

Key words: axons, regeneration, olfactory marker protein, olfaction, fish

In studies of teleostean olfactory systems, several investigators have described the concentric arrangement of cell types and resulting lamination of the olfactory bulb (Johnston, 1898, '02; Sheldon, '12; Holmgren, '20; Droogleever-Furtuyn, '61; Story, '64; Ichikawa, '76; Bass, '81a; Oka, '83). The laminar organization of teleost olfactory bulbs is less pronounced but generally comparable to that in mammals (reviewed in Allison, '53; Nieuwenhuys, '67; Andres, '70; Alonso et al., '89a). Studies using degeneration, axonal tracing, and electrophysiological techniques have demonstrated that the efferent axons arising from the medial and lateral regions of the olfactory bulb project primarily through the medial and lateral olfactory tracts, respectively, to partially segregated central projections (Scalia and Ebbesson, '71; Ito, '73; Braford and Northcutt, '74; Finger, '75; Satou et al., '79; Dubois-Dauphin et al., ' 80 ; Bass, ' $81 \mathrm{~b}$ ). This division into medial and lateral pathways may reflect the segregation of odor information associated with reproduction and feeding (Doving and Selset, '80; Stacey and Kyle, '83; Sorensen et al., '88; Satou, '90). Given the possibility of such functional segregation of the second order projections in the olfactory system, it is important to understand how the primary olfactory axons are organized and distributed within the glomerular layer of the olfactory bulb.

Recent anterograde and retrograde mapping experiments in trout have demonstrated that each point in the glomerular layer receives information from the entire olfactory rosette (Riddle and Oakley, '91). Here we extend our studies of the organization of the primary olfactory projection in trout, using tract tracing and immunocytochemical labeling to demonstrate major morphological subdivisions within that projection, which may reflect the segregation of axons into functional groups within the olfactory bulb. Olfactory receptor neurons were exposed to HRP applied to the mucosal surface in order to anterogradely label their projections to the olfactory bulb. In other trout, the distri-

Accepted June 26, 1992

Address reprint requests to David R. Riddle whose present address is Department of Neurobiology, Duke University Medical Center, Box 3209, Durham, NC 27710. 
bution of olfactory axons was characterized by immunocytochemistry. Neuroanatomical investigations of mammalian and amphibian olfactory systems have benefitted from the use of several antibodies and lectins that react with olfactory receptor neurons (Allen and Akeson, '85a,b; Fujita et al., '85; Hempstead and Morgan, ' $85 \mathrm{a}, \mathrm{b}$; Mori et al., '85; Schwob and Gottlieb, '86; Key and Giorgi, '86a,b; Morgan, '88; Barber, '89; Shinoda et al., '89). The most useful markers permit one to trace the trajectory of an identified group of neurons from source to termination in normal tissue. One of the antisera employed in the present study, anti-olfactory marker protein (anti-OMP), has been shown to bind to olfactory receptor neurons in a variety of vertebrates (Margolis, '80; Chuah and Zheng, '87; Baker et al., '89). In fish, OMP-like immunoreactivity (OMP-IR) has been detected previously by radioimmunoassay (Margolis, '80); the present study is the first immunocytochemical demonstration of OMP-IR in fish. In addition to the antiserum against OMP, we used antisera to keyhole limpet hemocyanin (anti-KLH) as a novel marker of olfactory receptor neurons.

As well as characterizing the organization of the primary olfactory projection in trout, this study provides new information regarding two other issues of interest to those studying the chemical senses of fishes-the presence of multiple receptor cell types and of a direct projection of primary olfactory afferents into the telencephalon. A number of investigators have demonstrated that there are at least two distinct types of olfactory receptor neurons in teleosts (reviewed in Yamamoto, '82, see also Rhein et al., '81; Zielinski and Hara, '88) and in mammals (Rowley et al., '89). One cell type bears a distinct olfactory knob with long cilia. The other has a less prominent apical knob bearing numerous microvilli. It has been suggested that in salmonid fishes (Salmo alpinus L., Salvelinus fontinalis, and Oncorhynchus mykiss), the two cell types represent functionally distinct classes (Thommesson, ' 82 , ' 83 ), that microvillous cells respond to amino acids and ciliated cells respond to bile salts. Other investigators, however, have been unable to find such a correlation in the catfish (Ictalurus punctatus) between morphology and functional specificity (Erickson and Caprio, '84). Even as the functional significance of these two cells types remains unresolved, other studies have provided evidence for yet a third class of receptor cells. Horseradish peroxidase (HRP) applied to the olfactory nerve or bulb of goldfish (Carassius auratus) and carp (I. punctatus) labeled ciliated cells with a wide dendrite terminating at the surface of the epithelium ('Type II ciliar cells, Muller and Marc, '84). We present additional evidence from both HRP and immunocytochemical studies that supports the existence of Type II ciliar receptor cells in trout, suggesting that at least three different olfactory receptor cell types cell types may be present in teleosts.

In addition to finding several morphological types of olfactory receptor neurons, these studies provide further evidence that a small subset of olfactory axons terminates caudal to the olfactory bulb. Each marker of olfactory receptor neurons used in this study also labeled olfactory nerve axons that projected through the olfactory bulb into the ventral-medial telencephalon.

\section{MATERIALS AND METHODS}

Rainbow trout (Oncorhynchus mykiss), 18-30 cm long, were obtained from Spring Valley Trout Farm (Dexter, MI) and maintained in 75 gallon aquaria at $14-16^{\circ} \mathrm{C}$. Trout were anesthetized for surgery with tricaine methane sulfonate (MS-222, $100 \mathrm{mg} / \mathrm{l}$ of aquarium water), wrapped in a wet towel, packed in ice and immobilized in a polystyrene holder. A constant stream of chilled aquarium water containing the anesthetic (MS-22, $80 \mathrm{mg} / 1$ ) flowed across the gills.

One olfactory mucosa in each of two normal fish was extensively labeled with horseradish peroxidase (HRP, Sigma type VI) so that the distribution of HRP-labeled olfactory axons could be examined. A pledget of gelfoam soaked in 5\% HRP was inserted through the anterior naris and placed against the olfactory rosette. The ipsilateral nares were then sealed with Parafilm and cyanoacrylate glue. Three weeks later the fish were re-anesthetized and perfused sequentially with heparinized physiological saline, fixative ( $1 \%$ paraformaldehyde and $1.25 \%$ glutaraldehyde in phosphate buffer), and $10 \%$ sucrose in phosphate buffer. Cryostat sections of the telencephalon and attached olfactory bulbs, the olfactory nerves, and the olfactory mucosae were thaw-mounted on gelatin-coated slides and HRP was visualized by means of tetramethyl benzidine (TMB, Mesulam, '82). Alternate sections of the mucosa were treated with diaminobenzidine (DAB), according to the intensification method of Adams ('81). The somal depth was determined for HRP-filled cells in the material treated with $\mathrm{DAB}$. For a labeled cell that appeared in its entirety in a single section, the distance from the epithelial surface to the center of the nucleus was measured with a calibrated eyepiece reticle.

Seven normal fish were anesthetized with MS-222 and perfused for immunocytochemistry with heparinized physiological saline followed by fixative $\left(6 \% \mathrm{HgCl}_{2}, 1 \%\right.$ sodium acetate, $0.1 \%$ glutaraldehyde). Six other normal trout were perfused with alternative fixatives (Bouin's fluid, 4\% paraformaldehyde, or $70 \%$ ethanol $10 \%$ acetic acid).

All tissue samples were dehydrated through graded alcohol, cleared in xylene and embedded in paraffin. Sections were cut at $7-10 \mu \mathrm{m}$ and mounted on gelatin-coated slides. Following rehydration, the $\mathrm{HgCl}_{2}$-fixed tissue was treated with alcoholic iodine followed by $5 \%$ sodium thiosulfate to remove residual mercury. All tissue was preincubated in $0.3 \% \mathrm{H}_{2} \mathrm{O}_{2}$ to block endogenous peroxidase activity, followed by $0.5 \%$ normal serum.

Sections of olfactory mucosae and bulbs fixed with Bouin's fluid, ethanol/acetic acid, or $\mathrm{HgCl}_{2}$ were incubated with antiserum to olfactory marker protein (anti-OMP, gift of F. Margolis, Roche Institute). The tissue was incubated in normal rabbit serum (NRS) followed by the OMP antiserum diluted 1:200 in NRS. Antibody binding was visualized by means of a biotinylated rabbit anti-goat secondary antibody (Sigma, St. Louis, MO), avidin-biotin-peroxidase complex (ABC, Vector Labs, Burlingame, CA) and DAB (Sigma).

In addition to the OMP antiserum, four commercially available polyclonal antisera were tested for reactivity in the olfactory system of the trout. Three of the antisera were raised against neuropeptides conjugated to $\mathrm{KLH}$ : luteinizing hormone-releasing hormone (anti-KLH/LHRH, Incstar, Stillwater, MN), substance P (anti-KLH/SP, Incstar), and vasoactive intestinal peptide (anti-KLH/VIP, Amersham, Arlington Heights, IL)). The three antisera were originally obtained to investigate the presence of the neuropeptides in the brain of the trout. After observing that the three antisera produced identical patterns of labeling and that the labeling could not be blocked by preadsorption with the 
neuropeptides (see Results), we were led to suspect that the observed reactivity actually resulted from antibodies against the KLH to which the peptides had been conjugated. This was confirmed by the elimination of the reactivity of the three antisera by preadsorption with KLH and also by using an antiserum against unconjugated KLH (U.S. Biochem, Cleveland, $\mathrm{OH})$. The antisera against $\mathrm{KLH}$ and $\mathrm{KLH}$ conjugates were used at final dilutions from $1: 1,000$ to $1: 10,000$ in normal goat serum (NGS). Antibody binding was detected with biotinylated goat anti-rabbit IgG (Sigma), $\mathrm{ABC}$, and $\mathrm{DAB}$. Immunocytochemical controls in cluded substitution of the primary antisera with NGS, substitution of the secondary antibody or $\mathrm{ABC}$ with buffer, preadsorption of the antisera to peptide conjugates with the appropriate neuropeptide (Sigma, 10-100 $\mu \mathrm{g} / \mathrm{ml}$ antibody solution), and preadsorption of each antiserum with KLH (U.S. Biochem., $10 \mu \mathrm{g} / \mathrm{ml}$ antibody solution).

In addition to our studies of normal trout, we lesioned the olfactory system in 18 trout in order to verify the identity of the neuronal elements labeled by anti-KLH and to compare the organization of the normal and regenerated systems. The fish were anesthetized as described above and a small hole was drilled in the midline of the skull at the level of the posterior margin of the orbit. The hole was enlarged with fine rongeurs to expose the olfactory bulbs and posterior portion of the olfactory nerves. In 9 of 18 trout, one olfactory nerve was transected approximately $1 \mathrm{~mm}$ anterior to the olfactory bulb and the cut ends of the nerve reapposed. In seven other trout, the olfactory bulb was resected and removed along with the posterior portion of the olfactory nerve. Gelfoam controlled occasional bleeding and was used to fill the hole in the skull. The incision was closed with 5-0 nylon sutures (Ethicon). Finally, in each of the two remaining trout, one olfactory rosette was exposed and extirpated with microscissors. The flow of fresh aquarium water across the gills revived the fish and restored vigorous opercular movement. After 2 to 14 weeks of recovery, the fish were re-anesthetized with MS-222 and perfused with the $\mathrm{HgCl}_{2}$ fixative as described above. Sections from both the lesioned and contralateral sides of the olfactory system of experimental fish were processed simultaneously so that immunoreactivity could be compared in lesioned and control tissue processed under identical conditions.

Following immunocytochemical labeling, we made camera lucida drawings of the glomerular layer from every fourth section of one olfactory bulb from each of four normal trout. Using a digitizing tablet and a microcomputer, we determined the total volume of the glomerular layer, the volume of each of the nine terminal fields, and the percentage of the total glomerular layer volume in each terminal field (See Table 1 footnote). In addition, for two fish in which the olfactory nerve had been transected 9-14 weeks prior, two-dimensional representations of the size and position of the normal and regenerated terminal fields were prepared and analyzed with a digitizing tablet and computer (See Fig. 10 legend).

\section{RESULTS}

The gross anatomy of the primary olfactory system in trout is similar to that in other salmonids (Pfeiffer, '63; Yamamoto, ' 82 ). The olfactory epithelium is located on the broad surfaces of 12-16 lamellae that radiate from the base of each of the bilaterally paired olfactory rosettes. The edges and tip of each lamella are covered with nonsensory epithelium, as are secondary folds that separate strips of olfactory epithelium on each face of the lamellae. The olfactory nerve, approximately $1 \mathrm{~cm}$ long in a $25 \mathrm{~cm}$ trout, emerges from the ventral posterior region of each rosette and projects to the ipsilateral olfactory bulb. The olfactory bulbs are sessile, i.e., directly attached to the telencephalon.

The results of the HRP and anti-OMP studies will be presented first, followed by the investigations of the normal and regenerated olfactory system using the novel marker of olfactory receptor neurons, anti-KLH.

\section{HRP labeling}

HRP applied to the olfactory epithelium labeled two distinct morphological classes of cells. Each cell had a fine basally directed process (arrows in Fig. 1A,B). The apical process of some cells ended in a 1-2 $\mu \mathrm{m}$ diameter knob that extended slightly above the surface of the epithelium (small arrowhead in Fig. 1B). The remaining HRP-filled cells had an apex approximately $4 \mu \mathrm{m}$ wide that ended flush with the epithelial surface (large arrowheads in Fig. 1A,B). All HRP-labeled cells fit into these two classes; there were no labeled cells with wide protruding apices or with narrow flat apices. The somata of labeled cells with wide apical processes were usually deeper in the olfactory epithelium than those of the cells bearing olfactory knobs. In two animals, the average somal depth of $280 \mathrm{HRP}$-filled receptor cells with dendritic knobs was $26 \pm 6 \mu$ m (mean \pm S.E.M.), while the mean somal depth of 400 cells with wide, flat apices was $38 \pm 8 \mu \mathrm{m}$.

HRP-filled axons were distributed throughout the olfactory nerve layer and glomerular layer of the ipsilateral olfactory bulb but were absent from the contralateral olfactory bulb (Riddle and Oakley, '91). The distribution of labeled axons within the glomerular layer was not continuous; rather the labeled fibers appeared to terminate in several discrete fields (e.g., Fig. 1C). The pattern of terminations appeared similar in both of the labeled fish. Fascicles of labeled axons projected through the olfactory bulb and into the ventral medial telencephalon.

\section{Olfactory marker protein}

Cells immunoreactive for the OMP antiserum were unevenly distributed in the olfactory epithelium. In some regions, immunoreactive cells were present every $3-5 \mu \mathrm{m}$, while in other areas, they were absent from stretches of olfactory epithelium more than $100 \mu \mathrm{m}$ long. All immunoreactive cells were intensely and similarly labeled. Each OMP-like immunoreactive cell had a stained axon, unstained nucleus, and a darkly stained dendrite that extended to the surface of the epithelium. The dendrites of a few immunoreactive cells ended in apical knobs, but most immunoreactive dendrites had a wide apex approximately 4 $\mu \mathrm{m}$ in diameter, which terminated flush with the epithelial surface (Fig. 2A).

OMP-like immunoreactivity was also evident in axonal bundles beneath the olfactory epithelium, in the olfactory nerve, and in the olfactory nerve layer and glomerular layer of the olfactory bulb (Fig. 2B). Some immunoreactive axons projected from the olfactory nerve through the olfactory bulb and into the ventral medial telencephalon, following the same path as the forebrain projection labeled by HRP. No other neurons in the forebrain were immunoreactive.

Omission of the OMP antiserum, the secondary antibody, or the $\mathrm{ABC}$ eliminated labeling. No attempt was made to 

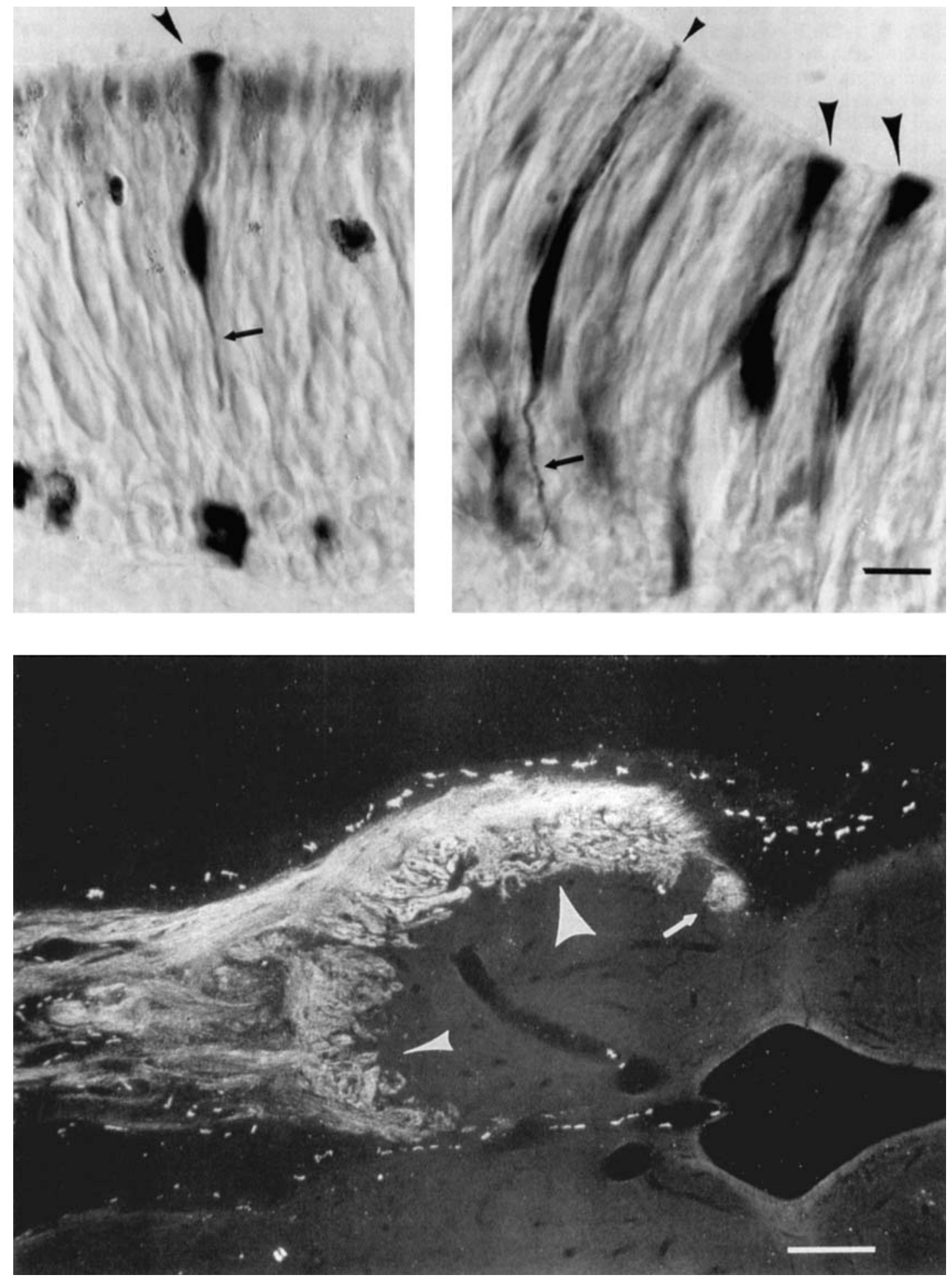

Fig. 1. Horseradish peroxidase (HRP) labeling in the primary olfactory system. A, B: Several HRP-filled cells are visible in these sections through the olfactory epithelium. Two distinct morphological classes of labeled cells are evident, one characterized by a narrow apex topped by an olfactory knob (small arrow), the other characterized by a wider apex terminating flush with the epithelial surface (arrowheads). Bar $=10 \mu \mathrm{m}$. C: Horizontal section through one olfactory bulb three weeks after the ipsilateral olfactory rosette was labeled with HRP (darkfield). The olfactory nerve enters from the left. At this level along the dorsal-ventral axis of the olfactory bulb, HRP-labeled axons project into three discrete terminal fields, anterior medial (small arrowhead), lateral (large arrowhead) and posterior lateral (small arrow). No HRP-labeled axons extend into the deeper laminae of the olfactory bulb. Bar $=250 \mu \mathrm{m}$ 

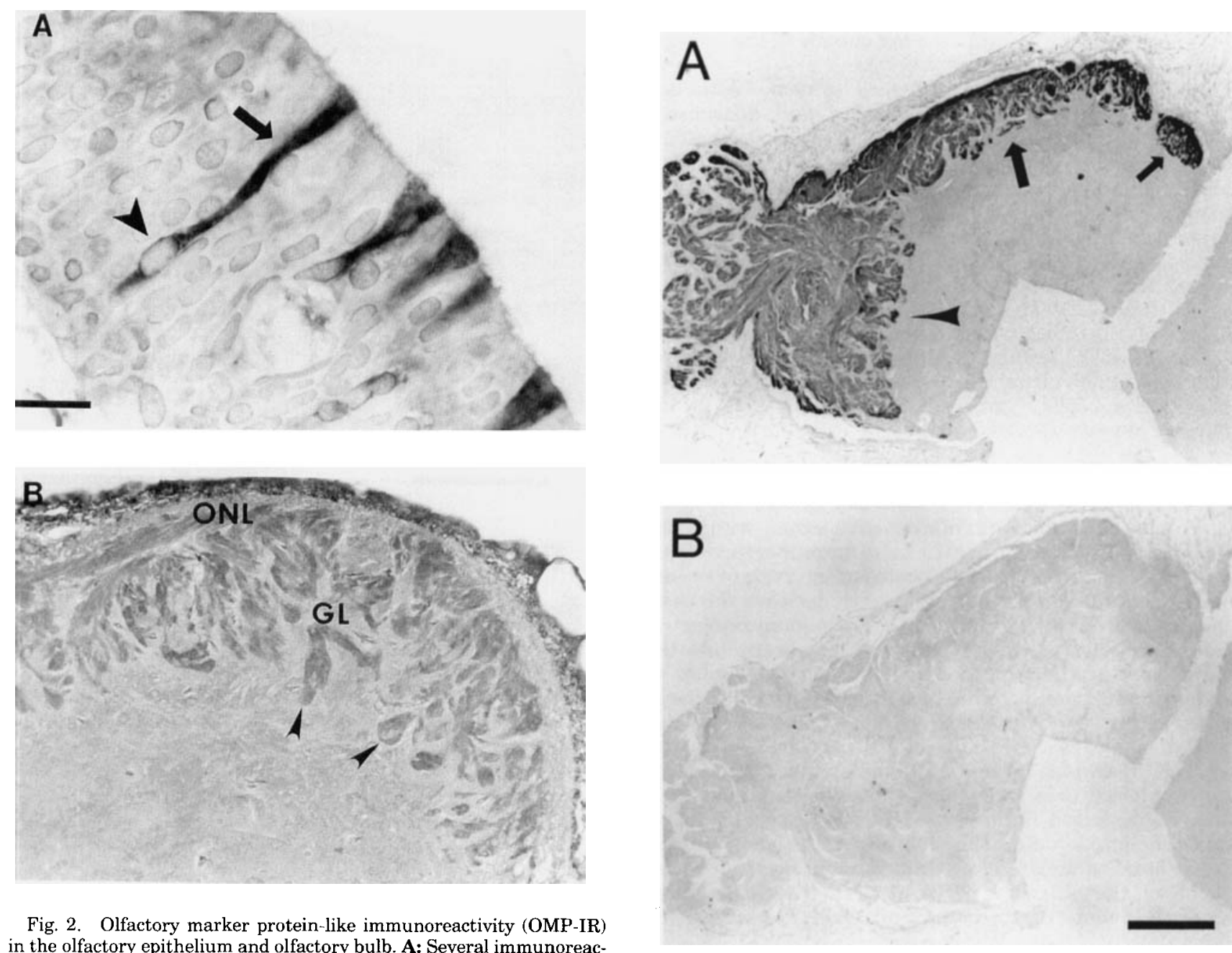

Fig. 2. Olfactory marker protein-like immunoreactivity (OMP-IR) in the olfactory epithelium and olfactory bulb. A: Several immunoreactive cells are visible in the olfactory epithelium. Note the unstained nucleus (arrowhead) and the broad dendrite (arrow), which extends apically and terminates flush with the surface of the olfactory epithelium. B: OMP-IR in this horizontal section of the olfactory bulb appears to be limited to the olfactory nerve layer (ONL) and glomerular layer (GL). The terminating axons form relatively discrete glomeruli similar to those seen in other vertebrates (arrowheads). Bar in $\mathrm{A}=10 \mu \mathrm{m}$ for $\mathrm{A}$ and $100 \mu \mathrm{m}$ for $\mathrm{B}$.

block the binding of the OMP antisera by preadsorption, thus it remains to be determined whether the molecule in trout recognized by the antisera is the same as mammalian OMP.

\section{KLH-like immunoreactivity}

Specificity of labeling. Antisera against $\mathrm{KLH}$ and against KLH conjugated to neuropeptides reacted intensely with trout olfactory receptor axons (see Fig. $3 \mathrm{~A}$ ). The four antisera produced almost identical labeling; anti-KLH/VIP produced slightly lower background reactivity than other equidiluted antisera. Reactivity was minimally affected by variation in fixation, although paraformaldehyde reduced the background slightly. Omission of the primary antiserum, the secondary antibody, or ABC, eliminated labeling. Preadsorption of each antiserum to a $\mathrm{KLH} /$ peptide conjugate with the corresponding peptide (e.g., preadsorption of anti-KLH/VIP with VIP) did not affect reactivity, even at

Fig. 3. Keyhole limpet hemocyanin-like immunoreactivity (KLHIR) in the olfactory bulb. A: Horizontal section from the olfactory bulb stained with anti-KLH/luteinizing hormone releasing hormone (LHRH), preadsorbed with LHRH $(100 \mu \mathrm{m} / \mathrm{ml}$ antiserum $)$. The same pattern of immunoreactivity was observed with antiserum that was not preadsorbed and with each of the four antisera tested. Immunoreactive axons are limited to the olfactory nerve layer and glomerular layer and project into discrete terminal fields, such as the anterior medial (arrowhead), lateral (large arrow) and posterior lateral (small arrow). Note that the pattern of labeled axons is similar to the distribution of HRP-filled axons in Figure 1C. B: This section, adjacent to A, is stained with anti-KLH/LHRH preadsorbed with KLH $(10 \mu \mathrm{m} / \mathrm{ml})$. KLH-IR is completely eliminated. $\mathrm{Bar}=250 \mu \mathrm{m}$ for $\mathrm{A}$ and $\mathrm{B}$.

an antigen concentration of $100 \mu \mathrm{g} / \mathrm{ml}$ of antiserum (Fig. 3A). We were unable to confirm the findings of Alonso et al ('89b, '90), who, using anti-VIP from another source, reported specific VIP-like immunoreactivity in rainbow trout olfactory nerve and bulb. Preadsorption of each of the four antisera with $\mathrm{KLH}(10 \mu \mathrm{g} / \mathrm{ml}$ antiserum) completely eliminated labeling (Fig. 3B). Since the four antisera produced identical patterns of reactivity, and since all immunoreactivity was eliminated by preadsorption with KLH while preadsorption with the neuropeptides had no effect, we concluded that all labeling was due to antibodies against $\mathrm{KLH}$, and hence, we refer to all reactivity as KLH-like immunoreactivity (KLH-IR). Characterizing the antigen(s) 
recognized by the KLH antisera lay outside of the scope of the present study.

KLH-IR in the normal olfactory system. Although KLH-IR was evident in both sensory and nonsensory epithelia in the olfactory mucosa, the pseudostratified columnar olfactory epithelium was easily distinguished from the less organized nonsensory epithelium covering the lamellar ridges. KLH-IR in the olfactory epithelium was pronounced in the membranes of spindle-shaped cellular processes oriented perpendicularly to the surface and extending from the middle of the epithelium to the apical surface (Fig. 4A). The intense immunoreactivity at the surface of the olfactory epithelium made it difficult to resolve the apical endings of individual cells. Nor could we easily distinguish olfactory receptor cell somata from those of supporting cells. Scattered large mucus cells in the olfactory mucosa were also immunoreactive (arrowhead in Fig. 4A). KLH-IR was intense in a few 6-8 $\mu \mathrm{m}$ diameter spheroidal cells scattered throughout the core of each lamella and in the base of the olfactory rosette. We could not resolve individual immunoreactive axons within the olfactory epithelium, but fascicles of immunoreactive axons, $2-8 \mu \mathrm{m}$ in diameter, were located at intervals of twenty to several hundred micrometers directly beneath the basal lamina (small arrows in Fig. 4A). Each immunoreactive fascicle projected from the basement membrane into the central core of the lamella and joined larger bundles of axons running parallel to the long axis of the lamella (large arrow in Fig. 4). The axonal bundles from all lamellae merged in the base of the rosette to form the olfactory nerve. KLH-IR was intense throughout the length of the olfactory nerve. Cross-sections of the nerve contained thousands of dispersed immunoreactive elements $2-5 \mu \mathrm{m}$ in diameter, approximately the same size as the glially limited axonal bundles apparent in transmission electron micrographs of the olfactory nerve of pike (Kreutzberg and Gross, '77) and trout (Riddle and Oakley, unpublished observations).

Within the trout brain, KLH-IR was largely limited to the primary olfactory afferents in the olfactory bulb and a small bundle of fibers that extended into the telencephalon. Immunoreactivity was intense in the olfactory nerve layer and glomerular layer (see Fig. 3A). No labeled neurons were apparent in the deeper layers of the olfactory bulb, but blood vessels were lightly labeled throughout the brain. A few small immunoreactive cells that lacked processes were scattered in the meningeal and periventricular regions of normal brains. Such cells were more common in lesioned fish. Their greater concentration around the lesion site suggests reactive gliosis.

The immunoreactive fibers in the glomerular layer ended in nine separate terminal fields (Figs. 5, 8-10). The positions of the nine fields were similar in all of the fish that we examined, and the relative size of each field was constant across the four individuals in which the size of the fields was measured. The largest terminal field comprised $35 \%$ of the total volume of the glomerular layer and the smallest about $1 \%$ (Table 1). Axonal fascicles, $2-6 \mu \mathrm{m}$ in diameter, often ended cohesively in spheroidal glomerular terminations up to $50 \mu \mathrm{m}$ in diameter (Fig. $5 \mathrm{~A}, \mathrm{~B}$ ), resembling the terminations described in other species (reviewed in Allison, '53; Nieuwenhuys, '67; Andres, '70). In contrast, olfactory axons in the two posterior lateral terminal fields ended in a diffuse brush pattern (e.g., Fig. 5C). To reach a given field, the fibers followed distinctive trajectories through the olfactory nerve layer. For example, the axons terminating in the posterior lateral field (PL) always coursed
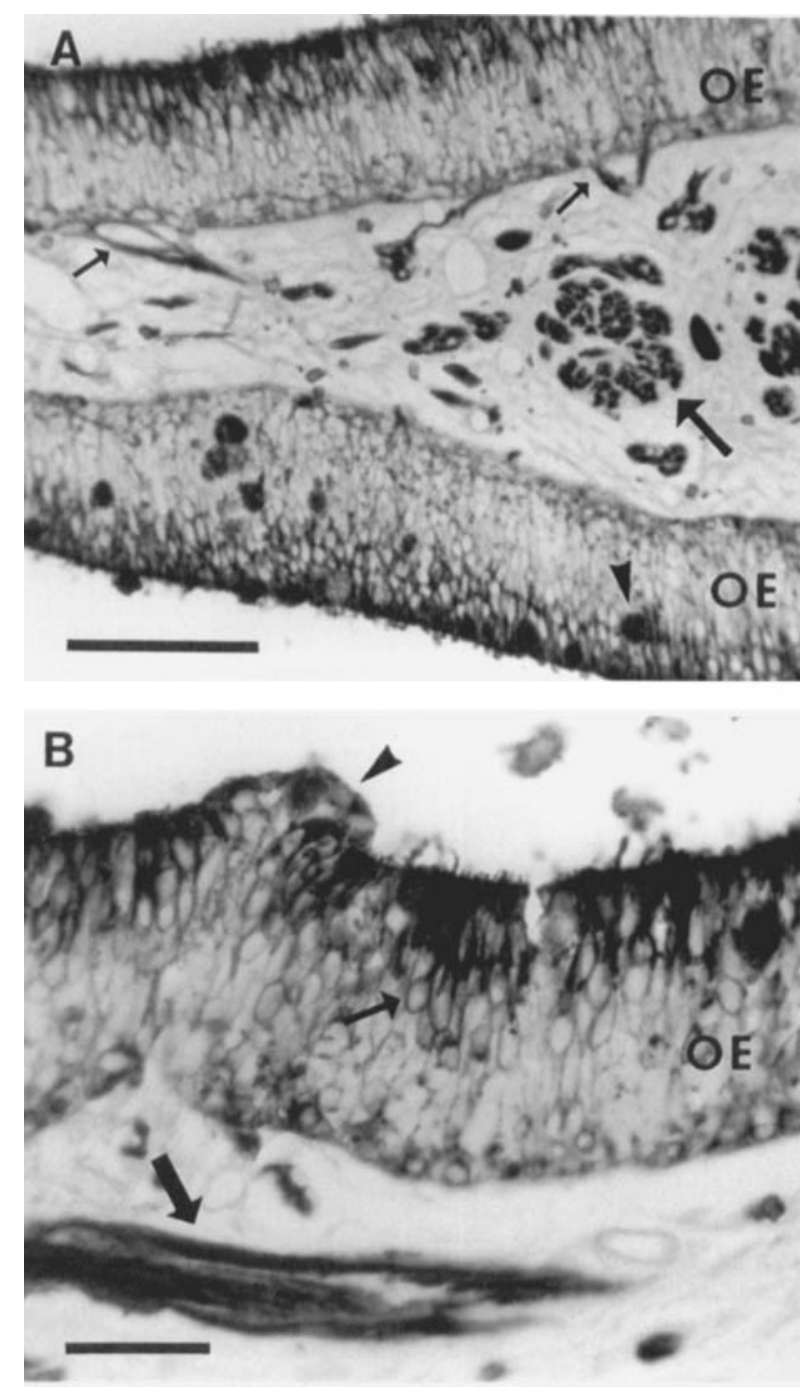

Fig. 4. KLH-IR in the olfactory mucosa. A: This section shows the olfactory epithelium (OE) on each face of the lamella, as well as the connective tissue core. Most cells in the olfactory epithelium appear to be immunoreactive. KLH-IR is particularly intense in the apical region. Fascicles of immunoreactive axons (small arrows) project from the basal lamina beneath the olfactory epithelium into the core of the lamella. These fascicles join larger bundles of immunoreactive axons (large arrow) that run parallel to the long axis of the lamella. A few immunoreactive mucus cells are also visible (arrowhead). Bar $=100$ $\mu \mathrm{m} . \mathrm{B}$ : Higher magnification of the olfactory epithelium reveals intense KLH-IR in the apical processes of cells whose cell bodies lie in the middle one-third of the alfactory epithelium (small arrow). No such immunoreactive processes are seen in the secondary ridge of nonsensory epithelium (arrowhead). Bundles of immunoreactive axons are visible beneath the basal lamina (large arrow). Bar $=30 \mu \mathrm{m}$.

posteriorly around the lateral face of the olfactory bulb. In contrast, the axons that supplied the ventral posterior lateral field (VPL), which lies immediately adjacent to PL, coursed along the ventral aspect of the bulb.

A discrete bundle of KLH-like immunoreactive fibers projected through the ventral medial olfactory bulb into the telencephalon (arrows in Fig. 6A), along the same path as axons labeled by HRP (Fig. 6B) and by anti-OMP (Fig. 6C). In some individuals, a few fibers from the ventral lateral olfactory nerve layer joined the bundle as it entered the 


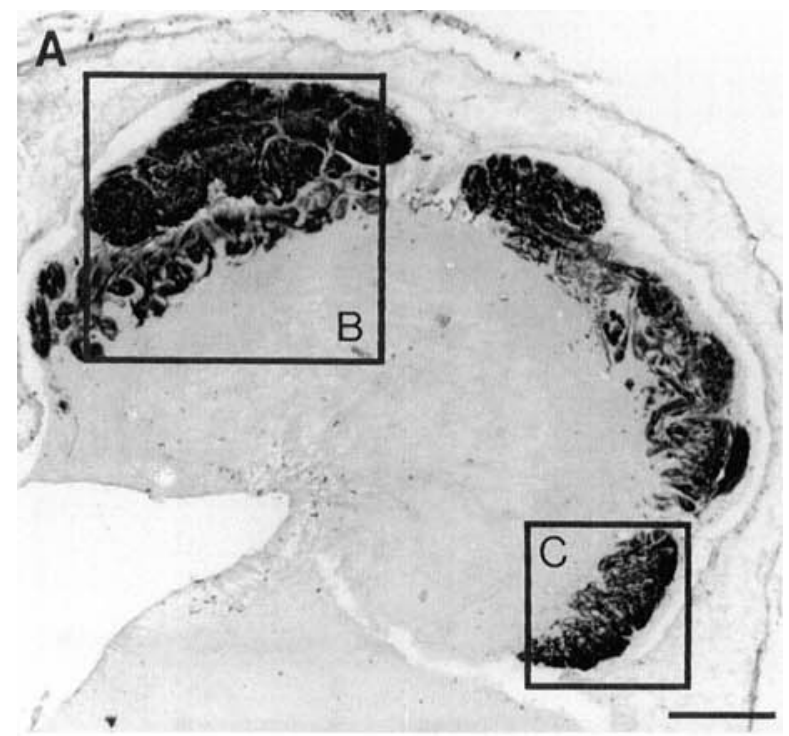

TABLE 1. Relative Size of the Nine Terminal Fields in the Trout Olfactory Bulb

\begin{tabular}{lc} 
Terminal field & $\begin{array}{c}\text { Volume in } \\
\text { percent (mean } \pm 1 \text { S.D.) }\end{array}$ \\
\hline Dorsal lateral (DL) & $17 \pm 2.0$ \\
Anterior medial (AM) & $30 \pm 3.0$ \\
Dorsal posterior medial (DPM) & $1 \pm 0.2$ \\
Dorsal posterior lateral (DPL) & $2 \pm 0.6$ \\
Lateral (L) & $35 \pm 0.8$ \\
Posterior lateral (PL) & $2 \pm 0.6$ \\
Ventral posterior lateral (VPL) & $1 \pm 0.2$ \\
Ventral posterior (VP) & $1 \pm 0.3$ \\
Ventral medial (VM) & $10 \pm 0.6$ \\
\hline
\end{tabular}

The volume of each field was determined by measuring its area in every fourth horizontal section, multiplying by the section thickness $(10 \mu \mathrm{m})$ and section interval (4), and summing the sections for each field. For each of four animals, the volume of each feld was divided by the total volume of the glomerular layer, i.e., the sum of all nine fields. The mean percentage volume for each field was then calculated for the four animals.

telencephalon. The bundle of KLH-like immunoreactive fibers coursed into the ventral medial telencephalon, where some axons appeared to terminate diffusely, a few crossed the anterior commissure and others proceeded posteriorly.

\section{KLH-IR after transection of the olfactory nerve, olfactory bulbectomy, and extirpation of the olfactory rosette}

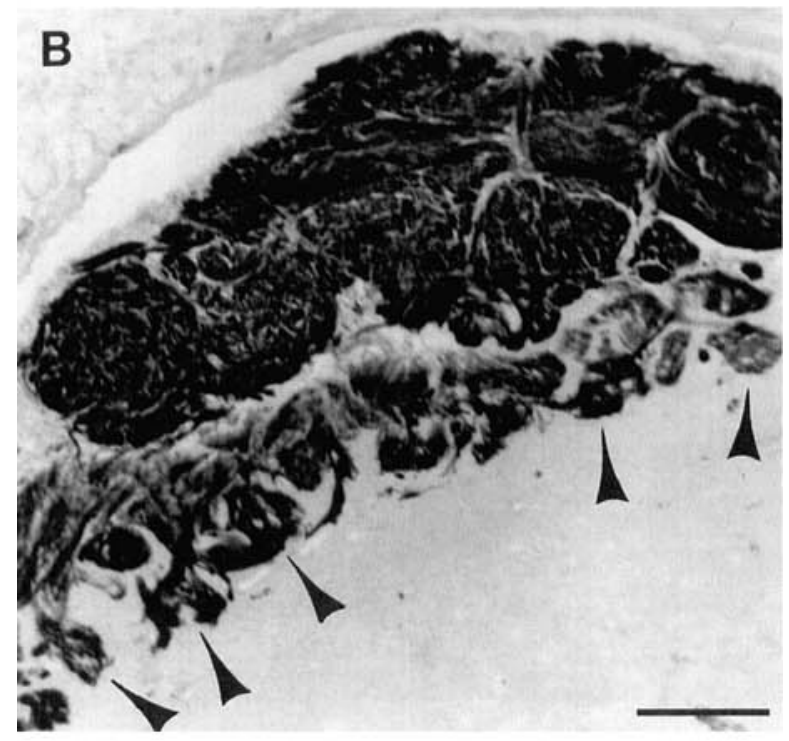

The changes in KLH-IR detected after unilateral lesions of the olfactory system were limited to ipsilateral structures.

Olfactory mucosa and nerve. Olfactory nerve transection produced a moderate decrease in KLH-IR in the olfactory epithelium and a marked, but transient, decrease in the axons in the lamellar core and in the olfactory nerve (Fig. 7). The maintenance of some immunoreactivity after nerve transection was likely due to the labeling of supporting cells (see Discussion). The loss of immunoreactivity in olfactory axons was most apparent four weeks after transection of the nerve $(\mathbf{n}=2)$. Axonal bundles within the olfactory rosette regained their normal KLH-IR by 9 to 14 weeks after transection $(n=5)$, while $K L H-I R$ within the olfactory nerve was still reduced. There were similar changes in KLH-IR in the olfactory mucosa and nerve after olfactory bulbectomy; KLH-IR decreased markedly in the axonal bundles within the rosettes and in the olfactory nerves.

Olfactory bulb. Olfactory nerve transection eliminated KLH-IR in the olfactory bulb within two to four weeks (Fig. $8 \mathrm{~A}$ ), except for a few KLH-IR fibers in the dorsal olfactory bulb and in a discrete group of glomeruli in the ventral medial terminal field (VM). Partial reinnervation of the olfactory bulb was evident six weeks after nerve transection, with the immunoreactive fibers most evident in the ventral and dorsal lateral regions of the olfactory bulb $(n=2)$. With longer survival periods, the axonal density increased and scattered fibers appeared laterally and posterior laterally (9-10 weeks, $\mathrm{n}=3$, Fig. $8 \mathrm{~B}$ ). By nine weeks, some olfactory axons were present in all terminal fields. Even fields remote from the entry point of the olfactory nerve, such as the posterior lateral field, received some

Fig. 5. KLH-IR in the olfactory bulb. A: Horizontal section through the olfactory bulb, approximately in the middle along the dorsal-ventral axis. Axons terminating in the anterior (enlarged in $\mathbf{B}$ ) and lateral terminal fields form glomerular endings (arrowheads in $B$ ). Those that terminate in the posterior lateral field form nonglomerular brush-like terminations (enlarged in C). Bars $=250 \mu \mathrm{m}(\mathrm{A}), 100 \mu \mathrm{m}(\mathrm{B})$ and 50 $\mu \mathrm{m}(\mathrm{C})$. 

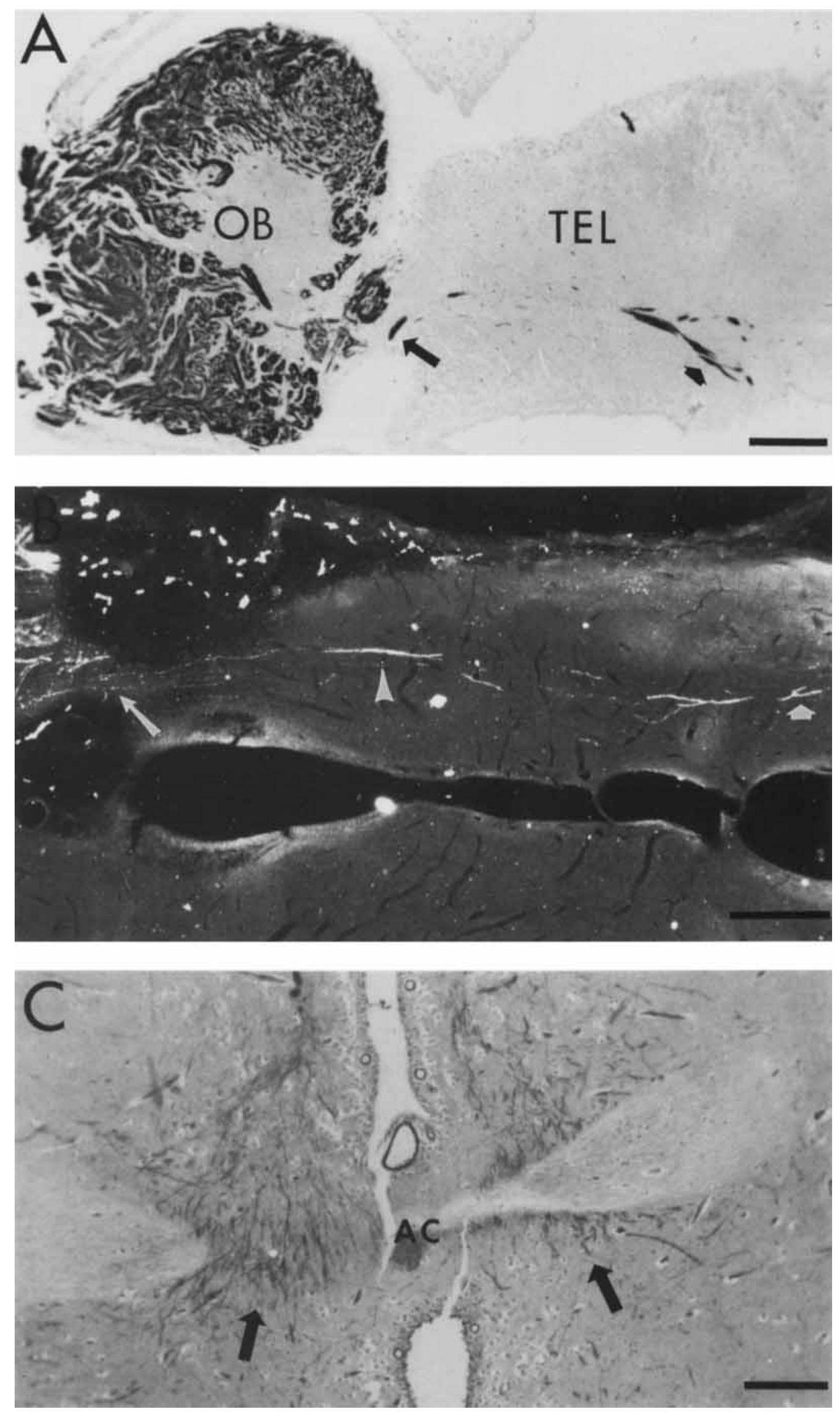
axons relatively early in the process of reinnervation. Thus, reinnervation did not proceed as a smooth wave that filled the anterior sites before advancing to the more posterior fields. Reinnervating axons appeared to return more or less contemporaneously throughout the glomerular fields in rough proportion to the normal density (Fig. 8B).

Reinnervation of all regions of the olfactory bulb increased with longer survival, but the apparent density of immunoreactive fibers in all terminal fields was still clearly below normal after 14 weeks $(n=2$, Fig. 9). The denervated olfactory bulb was noticeably smaller than the contralateral bulb due to marked thinning of the olfactory nerve layer (Fig. 9A). From 9-14 weeks, the pattern of terminal fields in the reinnervated olfactory bulbs matched that on the control side (Figs. 8-10).

Two fish euthanized six weeks after removal of one olfactory rosette had no KLH-IR fibers in the ipsilateral olfactory bulb, except in a small region in the ventral medial olfactory bulb where a few glomeruli remained. It is possible that the surviving fibers were from the contralateral nerve; contralateral projections by olfactory fibers have been reported in Xenopus and Rana (Ebbesson et al., '86; Duncan et al., '90). There was, however, no loss of immunoreactive fibers in the corresponding region of the olfactory bulb contralateral to the lesioned nerve. Further, we observed no contralateral projections in the HRP preparations, although it is technically possible that the ventral medial glomeruli originated from receptor cells that failed to take up HRP and were therefore not visualized by that method.

Telencephalic fibers. The telencephalic fascicle of KLHimmunoreactive fibers was absent ipsilaterally from fish euthanized four weeks after nerve transection. The telencephalic fascicle reappeared by six weeks after surgery, but remained small even after 14 weeks (see Fig. 8C). The ipsilateral telencephalic fascicle was absent in all five bulbectomized fish, and was also eliminated by ablation of the olfactory rosette.

\section{DISCUSSION \\ Morphological types of olfactory receptor neurons}

Previous investigations of the teleost olfactory system have demonstrated two receptor cell types, microvillous and ciliated. Both cell types have distinct apical knobs of roughly similar diameter, although the knob of microvillous cells is somewhat less prominent (Evans and Hara, '78;

Fig. 6. Axons projecting into the telencephalon were labeled by anti-KLH, by HRP applied to the olfactory rosette, and by anti-OMP. A: Horizontal section through the ventral olfactory bulb $(\mathrm{OB})$ and telencephalon (TEL), stained with anti-KLH. Immunoreactive axons enter the telencephalon from the ventral medial olfactory bulb (arrow) and project posteriorly to the level of the anterior commissure (blunt arrow). Bar $=250 \mu \mathrm{m}$. B: Horizontal section showing labeled fascicles in the telencephalon three weeks after the olfactory rosette was labeled with HRP (darkfield). Labeled axons enter the telencephalon from the ventral olfactory bulb (arrow) and project posteriorly through the telencephalon (arrowhead) to and beyond (blunt arrow) the level of the anterior commissure. Bar $=250 \mu \mathrm{m}$. C: Horizontal section through the ventral medial region of the telencephalon at the level of the anterior commissure (AC), stained with anti-OMP. Posterior is at the bottom. Many axons in the region of the anterior commissure are immunoreactive to anti-OMP (arrows). Immunoreactive axons could be followed in other sections from the ventral medial olfactory bulb posteriorly into the telencephalon to the area around the commissure. Bar $=100 \mu \mathrm{m}$.
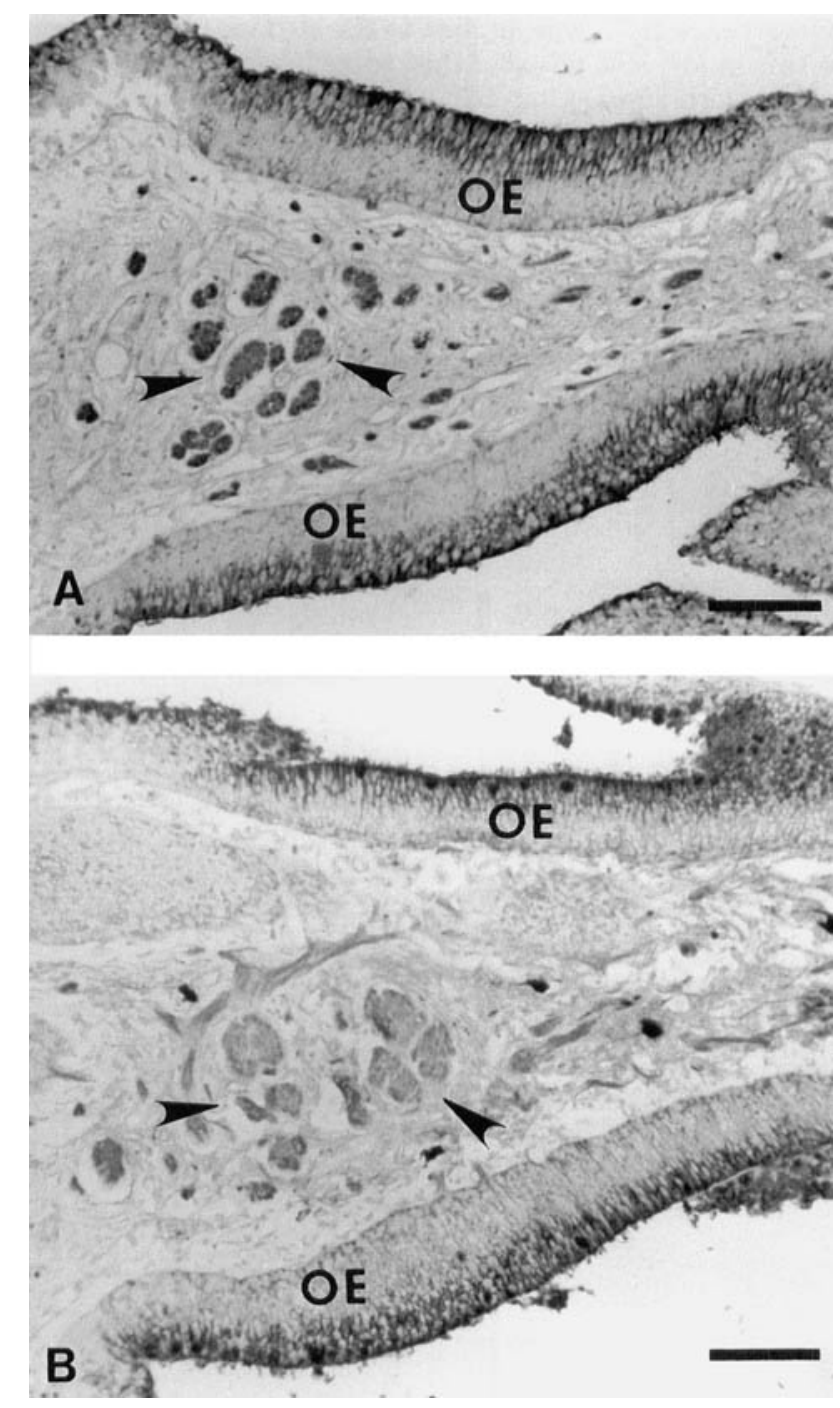

Fig. 7. Effects of olfactory nerve transection on KLH-IR in the olfactory mucosa. A: Four weeks after contralateral olfactory nerve transection, KLH-IR appears normal in the olfactory mucosa. There is intense KLH-IR in the apical region of the olfactory epithelium (OE) and in the axonal bundles in the core of the lamella (arrowheads). Bar = $100 \mu \mathrm{m}$. B: On the lesioned side, KLH-IR remains relatively intense in the olfactory epithelium, but is clearly reduced in the axonal bundles (arrowheads). Bar $=100 \mu \mathrm{m}$.

Rhein et al., '81; Muller and Marc, '84; Zielinski and Hara, '88). While some evidence from studies of salmonids has suggested that the two morphological types are also functionally distinct (Thommesson, '82, '83), studies using the channel catfish have not supported this functional distinction (Erickson and Caprio, '84). Thus, the functional significance of multiple cell types remains unclear. In the present study, HRP applied to the olfactory mucosa labeled some cells with olfactory knobs, and another class of cells with wider dendrites that lacked apical knobs. Rhein et al. ('81) identified similar "Type II ciliated cells" in the olfactory mucosa of trout without commenting on their function. Muller and Marc ('84) concluded that similar cells in the olfactory mucosa of goldfish and catfish were receptor neurons since they were retrogradely labeled by HRP injected into the olfactory bulb or applied to the olfactory 
nerve. Since HRP was applied to the surface of the mucosa in this study, it is possible that some labeled cells with flat heads were supporting cells. Most of the cells, however, appeared to have axons. Further, we noted in an earlier
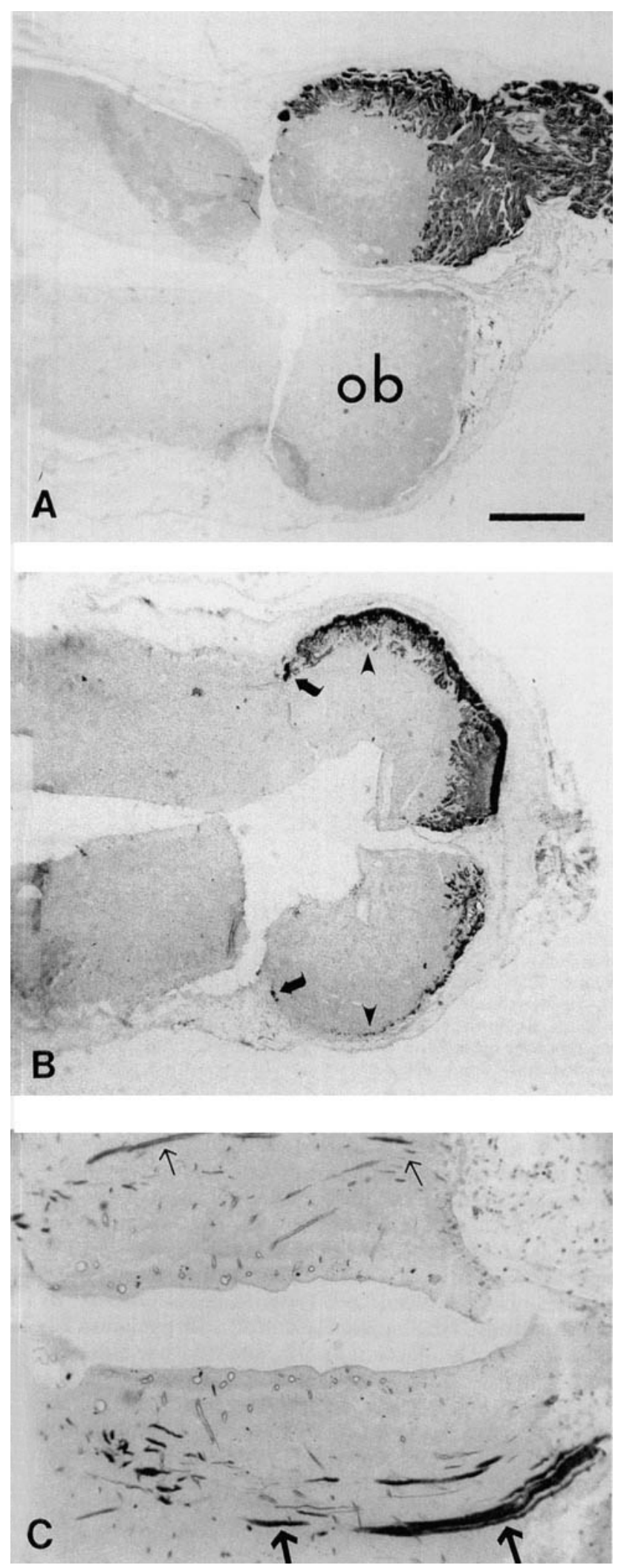

study that cells with similarly wide, flat apices were labeled by fluorescent beads injected into the olfactory bulb (Riddle and Oakley, '91). Moreover, in the present study, cells with identical morphology were intensely stained by antisera to OMP. OMP-IR has been recognized as a relatively specific marker for mature olfactory receptor neurons in other vertebrates (Margolis, '80; Baker et al., '89). It remains to be determined, of course, whether the molecule recognized by the OMP antisera is the piscine homologue of mammalian OMP. Regardless, the fact that axons throughout the olfactory nerve layer and glomerular layer were OMPpositive while there were virtually no OMP-positive cells with the classical morphology of receptor neurons (i.e., with knobs), suggests that the Type II ciliar cells in the OMP preparations were mature receptor neurons. This argument assumes only that the OMP antiserum recognizes the same population of receptor cells in the epithelium and in the olfactory bulb. Taken together, the observations with OMP antiserum, anterograde HRP labeling and retrograde labeling with fluorescent beads make it likely that the flat-headed cells are olfactory receptor cells, with some sufficiently mature to have extended axons into the olfactory bulb.

We considered the possibility that the olfactory receptor cells with dendritic knobs and those with wide, flat apices represented the extremes of a morphological continuum associated with receptor cell maturation. It is often noted that the dendrites of olfactory receptor cells in mammals become stouter as the cells mature and their somata migrate toward the epithelial surface. This cannot explain the wide dendrites of the Type II cells since their somata were located more deeply in the epithelium than the somata of the cells with distinct dendritic knobs. Thus, if the different morphologies represent different maturational states, in fish the Type II cells with wider dendrites would be the younger cells.

Further investigations will be required to characterize the different morphological types of olfactory receptor neurons, and to evaluate the significance of those putative olfactory receptor cells that displayed OMP-like immunoreactivity. It remains to be determined whether these morphologically distinct cells are equally distinctive in their response properties. Future investigations may be facilitated by the use of markers like those applied in this study, since our observations indicate that the different cell types differ somewhat in their antigenic properties.

\section{Axons of the olfactory nerve make direct projections into the telencephalon}

A number of studies using immunocytochemical labeling and tract tracing have demonstrated neural connections between the olfactory mucosa and various telencephalic regions posterior to the olfactory bulb. Demski and Northcutt reported that HRP applied to the olfactory mucosa of

Fig. 8. KLH immunoreactivity in horizontal sections of the olfactory bulb 2-10 weeks after unilateral olfactory nerve transection. A: The ipsilateral olfactory bulb (ob) had no KLH-IR 14 days after transection of the right olfactory nerve. B: Significant reinnervation is evident 9 weeks after transection of the right olfactory nerve. Some axon terminations are present even in the lateral field (arrowheads) and in the posterior lateral field (arrow), which corresponds exactly with the position of the posterior lateral field on the normal side (arrow). C: Ten weeks after transection of the left olfactory nerve, some KLHimmunoreactive axons are present (small arrows) that resemble the more robust telencephalic projections on the normal side (large arrows). Bar in $\mathrm{C}=40 \mu \mathrm{m}$ for $\mathrm{A}-\mathrm{C}$. 


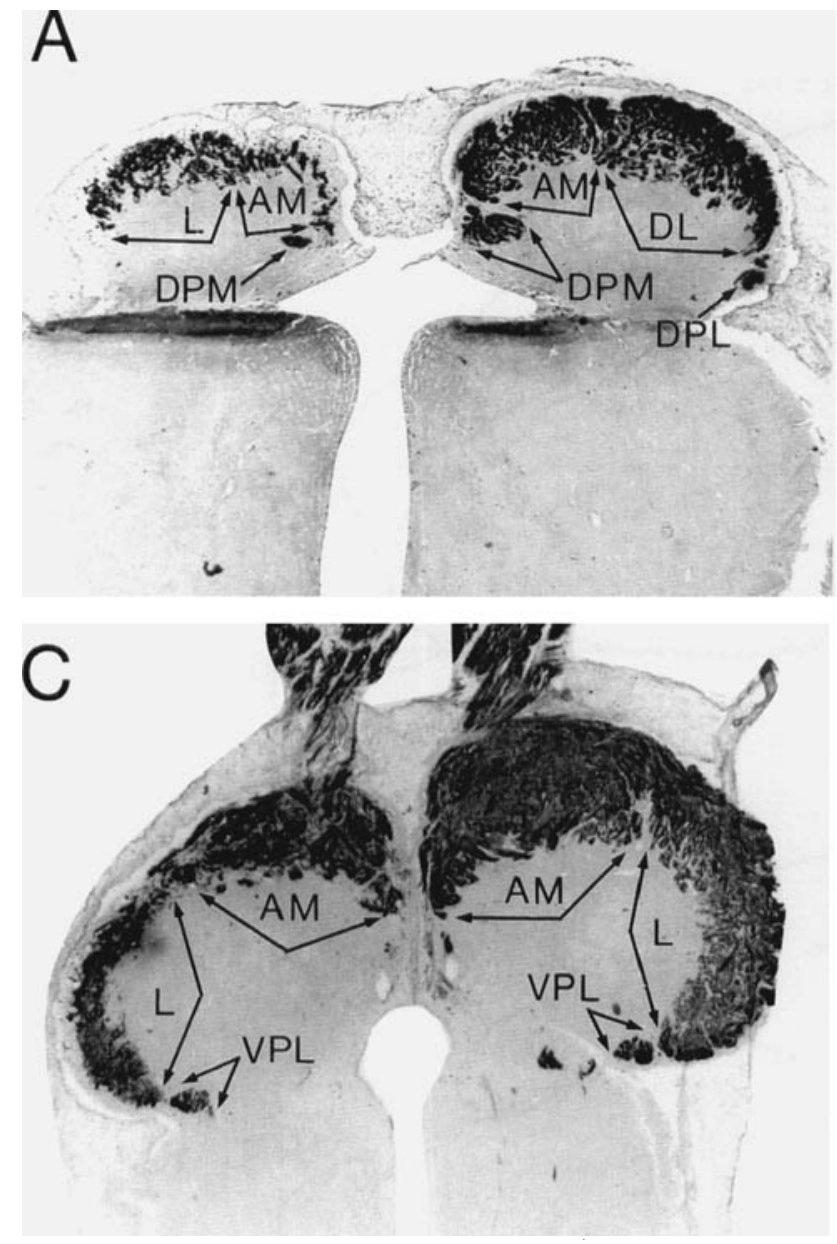

Fig. 9. Four sequential (dorsal to ventral) horizontal sections through the olfactory bulbs of a trout 14 weeks after unilateral (left) olfactory nerve transection. Nine terminal fields can be identified in these sections in the right (control) olfactory bulb: A: The most ventral regions of the dorsal posterior medial (DPM) and dorsal posterior lateral (DPL) terminal fields are visible along with the anterior medial (AM) and dorsal lateral (DL) fields. B: Field AM continues ventrally where the lateral (L) and posterior lateral (PL) fields come into view. C:

the goldfish labeled axons that projected into the ventral medial telencephalon. They concluded that the fibers belonged to the terminal nerve (Demski and Northcutt, '83; Demski, '84). Bazer et al. ('87) reported that cobaltous lysine applied to the olfactory mucosa of salmon fry labeled axons that followed a similar trajectory, but concluded that the fibers may have been labeled by transynaptic transport of the label. In the present study, telencephalic fibers were labeled by HRP applied to the olfactory mucosa of mature trout. It is unlikely that the labeled fibers were the result of transynaptic labeling since unconjugated HRP is not thought to cross synapses. Thus, our findings raise the possibility that the telencephalic fibers observed in Bazer's study may have been labeled directly, and that axons linking the olfactory mucosa and the ventral medial telencephalon may be present in both young and mature salmonids as well as in a variety of other fish (see von Bartheld et al., ' 88 ). The pathway followed by the fibers into and within the telencephalon of the trout is generally consistent with the location of terminal nerve axons in other fishes (Munz et al., '82; Munz and Claas, '87; Capron de Caprona et al., '86; von Bartheld et al., ' 88 ). If the fibers belong to the
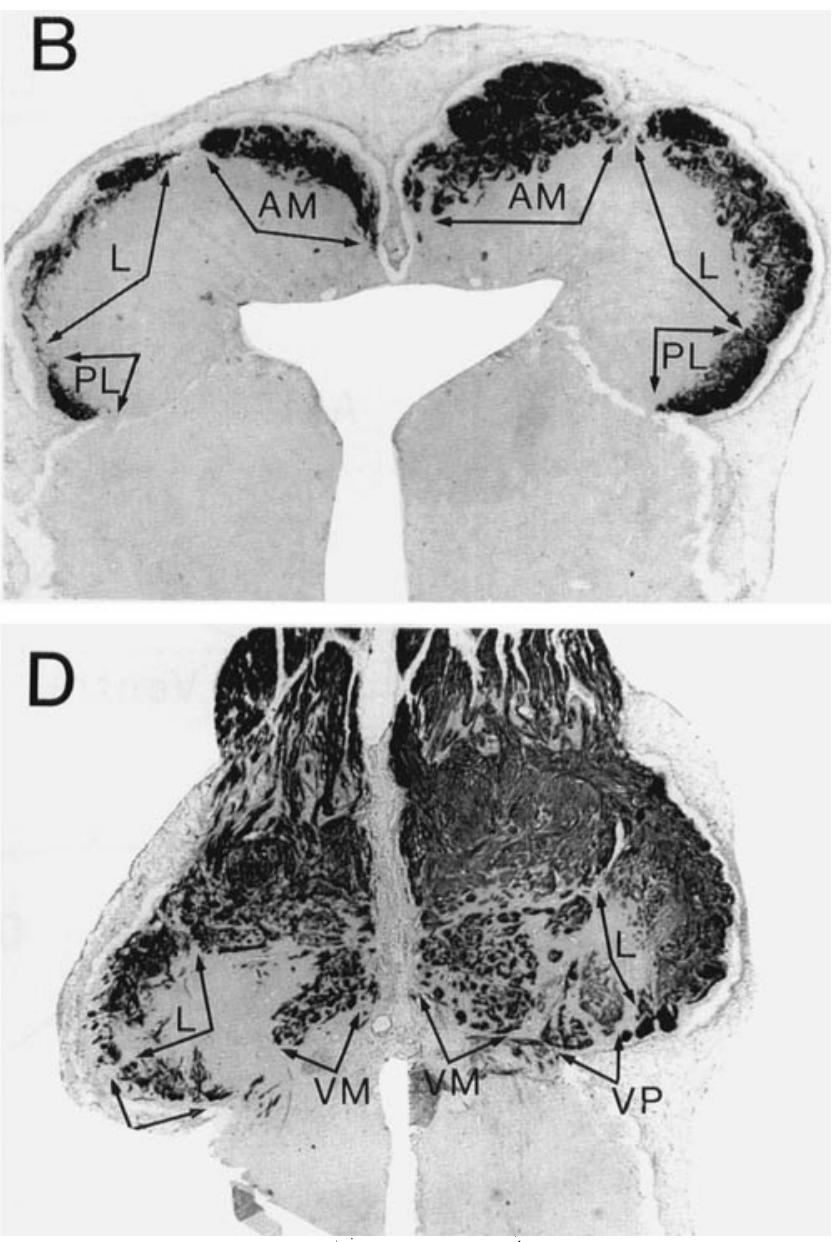

Fields AM, L, and PL continue further ventrally where a small portion of the ventral posterior lateral (VPL) field is apparent. D: The ventral medial (VM) and ventral posterior (VP) fields can be seen in the most ventral section.

Despite the decreased density of innervation, these terminal fields can be identified in the reinnervated olfactory bulb (left). Reconstitution of the terminal fields is particularly evident for DL in A, PL in B, L in $\mathrm{C}$, and VM in D. Bar $=250 \mu \mathrm{m}$ for $\mathrm{A}-\mathrm{D}$.

terminal nerve, however, it is somewhat surprising that we could not demonstrate gonadotropin releasing hormone (GnRH) reactivity, since immunoreactivity for GnRH is characteristic of teleostean, amphibian and mammalian terminal nerve axons (Jennes and Stumpf, ' 80 ; SchwanzelFukuda and Silverman, '80; Munz et al., '82; Stell et al., '84; Wirsig and Getchell, '86; Munz and Claas, '87; SchwanzelFukuda et al., '87; Stell and Walker, '87; von Bartheld et al., '88). Perhaps the axons projecting into the trout telencephalon would react to antibodies against teleostean $\mathrm{GnRH}$ (Kah et al., '86). However, two other observations suggest that the labeled telencephalic fibers were not part of the terminal nerve. Each marker of olfactory receptor neurons also labeled the telencephalic fascicle, consistent with a direct projection of primary olfactory axons into the ventral medial telencephalon. Of course it is possible that the antibodies recognized different antigens in receptor neurons and in the telencephalic fibers or that olfactory and terminal nerve fibers share the same antigen(s). The loss of the telencephalic fibers after ablation of the olfactory mucosa, however, implies that the somata associated with the telencephalic fibers were not located in the olfactory 


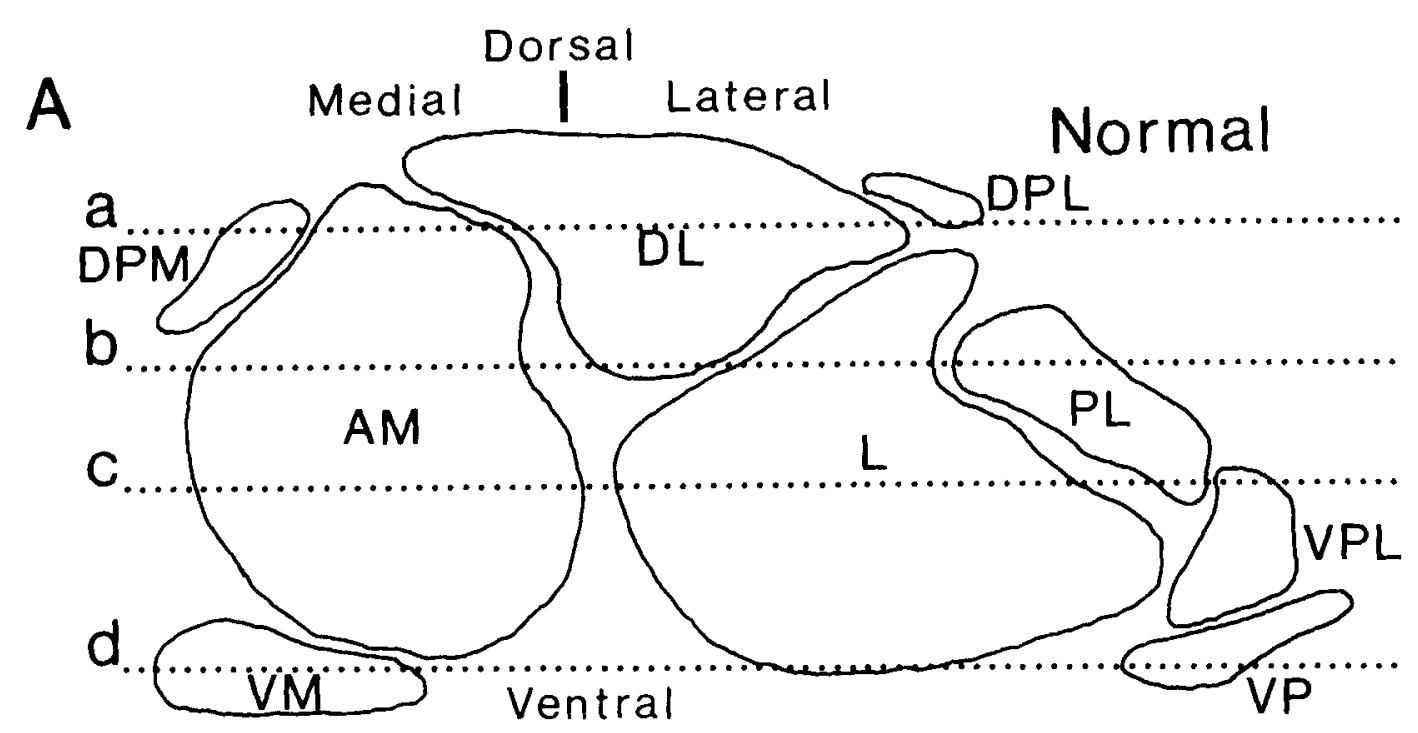

B
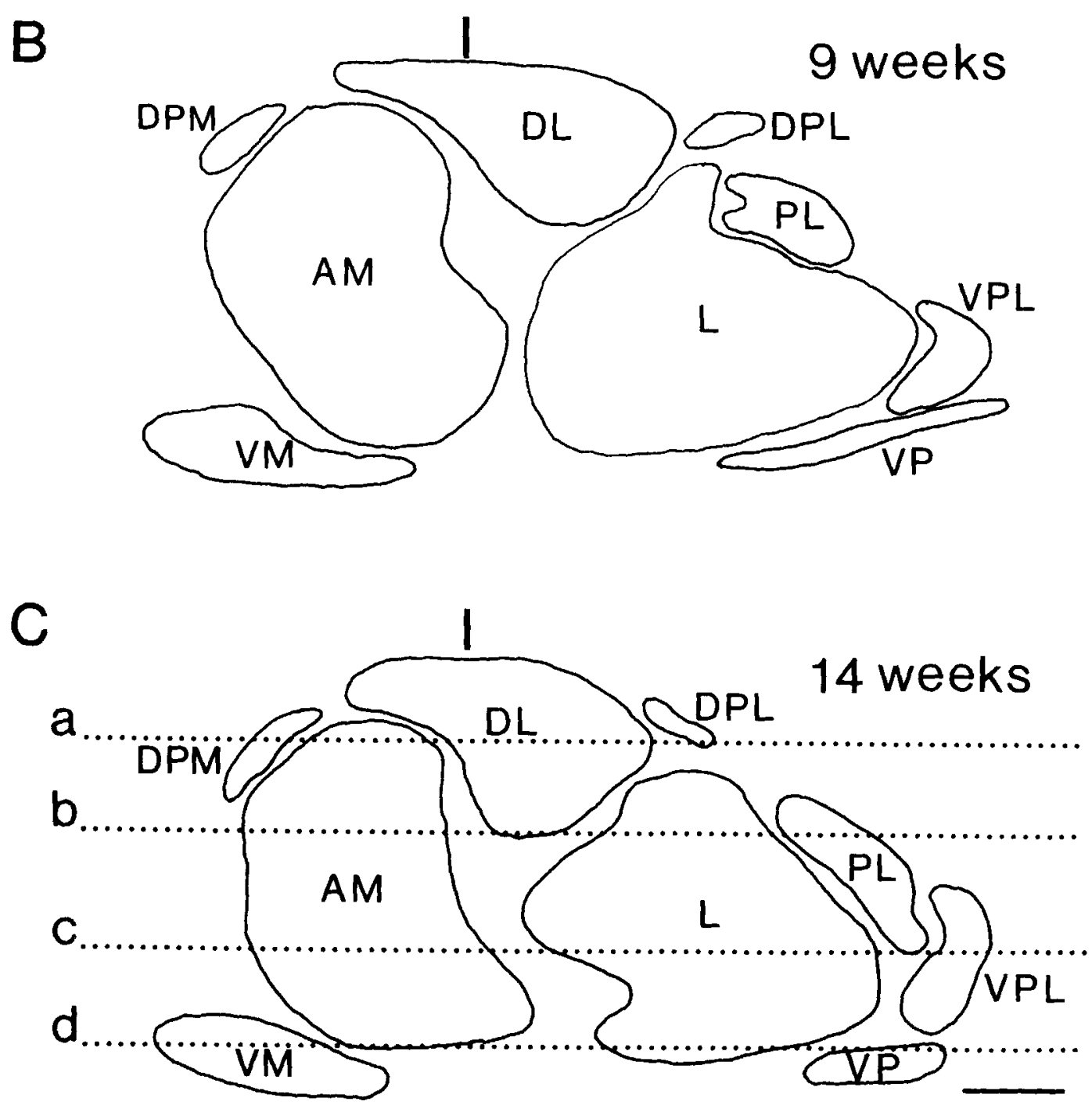

Figure 10 
nerve or in the telencephalon (in contrast to the ganglion cells of the known terminalis system). Rather, it seems more likely that the fibers were primary olfactory afferents. Such direct projections of primary olfactory afferents past the olfactory bulb and into the telencephalon were recently described in several gymnotid fishes (Gymnotus carapo, Hypopomus sp., Apteronotus leptorhynchus, Szabo et al., '91) and in the three-spined stickleback (Electrophorus electricus, Honkanen and Ekstrom, '90). Thus, our observations represent the third family of fishes in which such a direct projection of primary olfactory axons into the ventral medial telencephalon has been revealed.

\section{Organization of the normal and regenerated primary olfactory projections labeled with anti-KLH}

The antisera to KLH greatly facilitated the evaluation of the organization of the normal and regenerated primary olfactory projection in trout. The evidence of KLH-IR in both supporting cells and olfactory receptor cells may reflect their common derivation from the olfactory placode. Alternatively, it is possible that a molecule recognized by the antisera is secreted by one cell type and taken up by the other, or that different molecules in the two cell types share a common epitope. In any case, the maintenance of KLH-IR in the olfactory epithelium following olfactory nerve transection was probably due in part to the immunoreactivity of supporting cells, but may also reflect on-going and experimentally induced olfactory receptor neuron replacement.

While KLH-IR was nonspecific in the mucosa, its high specificity in the brain for olfactory axons made it a valuable probe for characterizing the organization of those afferents. We infer from the pattern of anti-KLH labeling that olfactory axons undergo little fasciculation until they collect near exit points scattered along the basal lamina, since immunoreactive axons were not evident in the superficial olfactory epithelium. (Individual axons would probably be too small to detect--see below.) The trajectory of fascicles from the basal lamina to the olfactory bulb was easily followed in the anti-KLH preparations. With the possible exception of a few axons terminating in the VM terminal field, the KLH-like immunoreactive axons from each olfactory rosette reached the olfactory bulb through the ipsilateral olfactory bulb. Thus, immunoreactive fibers in the

Fig. 10. Schematic maps of the nine terminal fields shown in one normal olfactory bulb $(\mathbf{A})$ and in two olfactory bulbs 9 weeks $(\mathbf{B})$ and 14 weeks (C) after transection of the olfactory nerve. Abbreviations are the same as in Figure 9. The maps in $A$ and $C$ were prepared from the olfactory bulbs shown in Figure 9 ; the positions of the horizontal sections shown in that figure (A through D) are indicated by dotted lines. These flattened two-dimensional representations of glomerular terminal fields were prepared from anti-KLH-stained horizontal sections. Camera lucida drawings were made of the boundaries of the terminal fields evident in every fourth horizontal section. The linear extent of each terminal field and the distance between fields was measured using a digitizing tablet. This produced for each horizontal section a straight line as long as the circumference of the glomerular layer with the terminal fields and inter-terminal regions indicated by tic marks. These lines were arranged from dorsal to ventral, using the center of the anterior face of the olfactory bulb as a fiducial mark. Terminal field boundaries were drawn by interconnecting the tic marks in this stack of lines. The left end of the dashed lines in each figure is the posterior medial extent of the glomerular layer, while the right end is the posterior lateral margin. Compared to the normal side each terminal field is slightly reduced in size in the reinnervated bulb; however, the relative sizes and the pattern of the terminal fields are quite similar. Bar $=0.5 \mathrm{~mm}$ for $\mathrm{A}-\mathrm{C}$. ipsilateral olfactory bulb were lost temporarily after transection of the olfactory nerve and apparently permanently after extirpation of the olfactory rosette. There was no evidence for olfactory axons that lacked KLH-IR, although scattered unstained olfactory axons would have been too small $(0.2 \mu \mathrm{m}$ diameter $)$ to detect by light microscopy (Gasser, '56; Riddle and Oakley, unpublished ultrastructural observations). In both cross-sections and longitudinal sections of the olfactory nerve, the trajectories of immunoreactive axons appeared to remain parallel to the long axis of the nerve. Hence, fascicles of axons from small subregions of the epithelium probably remain in parallel bundles until the axons are redistributed by extensive resorting as the fibers enter the olfactory bulb (see Fig. 9D).

After entering the olfactory bulb, the primary axons are organized in a very consistent fashion. This study has shown that the glomerular layer in the olfactory bulb of the trout is organized into discrete terminal fields that are consistent in pattern across individuals and that the axons that terminate in each field follow distinctive trajectories through the olfactory nerve layer. While this organization was initially recognized in the material reacted with the KLH antisera, it was also evident in the HRP and anti-OMP preparations (compare for example, Figs. $1 \mathrm{C}$ and $3 \mathrm{~A}$ ). We have identified nine fields, but recognize the possibility that some of the larger fields might be further sub-divided. We based our classification on three criteria. First, the nine fields were bounded by narrow sectors of the glomerular layer that lacked stained axons. Second, the appearance of the fiber terminations was consistent within each field; in some fields the terminations were brush-like, in others glomerular. Third, each field was easily recognized in every trout examined, whereas less clearly demarcated, finer subdivisions varied from animal to animal.

The presence of the same nine terminal fields in fish of different sizes and ages (Riddle and Oakley, unpublished observations) suggests the fields are probably maintained over time as new olfactory receptor cells are added and the old cells replaced. A stable pattern of terminal fields is suggested by the small variance in the relative size of the terminal fields among individual trout (Table 1). When challenged by experimental nerve transection, the primary olfactory system restored itself by replacing the terminal fields. There did not appear to be an initially random ingrowth of axons followed by pruning into discrete fields; rather, the returning axons appeared to respect the boundaries of the terminal fields. Further, despite the earlier reappearance of the dorsal and lateral terminal fields, reinnervation did not occur as a wave of axons that filled all termination sites near the olfactory nerve before progressing posteriorly. Remote termination sites received some reinnervation early on, and the density of fibers in the more anterior fields was still subnormal while the posterior fields were being reformed. Despite the slow rate of olfactory nerve reformation (Cancalon, ' 85 ), by three to four months after nerve transection the reinnervating axons terminated in the normal pattern of terminal fields, albeit with fewer axons (Figs. 8-10). While it is unknown how axon-target interactions contribute to terminal field formation, it seems likely that terminal field reconstitution following nerve transection utilizes mechanisms similar to those employed during normal receptor cell turnover.

It is interesting to consider whether the parcellation into glomerular terminal fields in trout corresponds to functional segregation comparable to the macroglomerulus in the insect olfactory lobe (Boeckh and Boeckh, '79; Matsu- 
moto and Hildebrand, '81; Hansson et al., '92) and the modified glomerular complex in the rodent olfactory bulb (Teicher et al., '80; Greer et al., '82). The macroglomerulus and the modified glomerular complex are believed to process information about specific odorants of behavioral importance. Electrophysiological studies have demonstrated functional segregation in the olfactory bulb of artic char and rainbow trout (Salmonidae) that might correspond to the dorsal lateral (DL) and anterior medial (AM) terminal fields. Recording from the dorsal surface of the olfactory bulb, Thommesen and Doving found that amino acids elicited greater responses laterally while the responses to bile salts were greater medially (Thommesen, '78; Doving et al., ' 80 ). It should be possible to combine electrophysiological mapping with anti-KLH immunocytochemistry in order to characterize the responses within different terminal fields. It would be particularly interesting to evaluate the response characteristics of fibers in the posterior lateral glomerular layer. With their unusual brush-like terminations, these axons may have a special functional role. It should be noted that morphological differences in olfactory terminals are not limited to the trout; two regionally segregated classes of terminals have been reported in the olfactory bulb of the goldfish (Finger, '88).

\section{Summary and conclusions}

Anterograde tract tracing with HRP and immunocytochemistry with antisera against olfactory marker protein and keyhole limpet hemocyanin revealed the pathways of olfactory axons and the pattern of their terminations in the olfactory bulb of rainbow trout. These methods distinctly labeled olfactory receptor neurons, including a class of apparent receptor cells with a wide dendrite that lacked an olfactory knob and a subset of olfactory nerve axons that projected directly into the ventral medial telencephalon. The bulk of the labeled axons terminated in the glomerular layer of the trout olfactory bulb and were organized into nine distinctly positioned terminal fields, ranging in size from 1 to $35 \%$ of the glomerular layer. In some terminal fields, the olfactory axons made glomerular-like terminations, in others brush-like terminations. The nine terminal fields, which may reflect functional parcellation of olfactory information, were substantially reconstituted by 14 weeks after unilateral transection of the olfactory nerve. These observations on olfactory receptor cell types and the organization of their projections provide a foundation for continuing investigations relating the anatomical organization of the olfactory system to its function. In addition, the molecular markers described here will be useful for studying the development of the terminal fields and the means by which this organization is maintained during the continual replacement of olfactory receptor cells.

\section{ACKNOWLEDGMENTS}

We thank L.H. Wu and L.D. Wong for technical assistance, and $M$. Riggott for critically reading the manuscript.

\section{LITERATURE CITED}

Adams, J.C. (1981) Heavy metal intensification of DAB-based HRP reaction product. J. Histochem. Cytochem. 29:775.

Allen, W.K., and R. Akeson (1985a) Identification of a cell surface glycoprotein family of olfactory receptor neurons with a monoclonal antibody. J. Neurosci. 5:284-296.

Allen, W.K., and R. Akeson (1985b) Identification of an olfactory receptor neuron subclass: Cellular and molecular analysis during development. Dev. Biol. 109:393-401.

Allison, A.C. (1953) The morphology of the olfactory system in the vertebrates. Biol. Rev. 28:195-244.

Alonso, J.R., C. Pinuela, E. Vecino, R. Covenas, J. Lara, and J. Aijon (1989a) Comparative study of the anatomy and laminar organization in the olfactory bulb of three orders of fresh water teleosts. Gegen. Morphol. Jahrb. 135:241-254.

Alonso, J.R., R. Covenas, J. Lara, M. de Leon, and J. Aijon (1989b) Distribution of vasoactive intestinal peptide-like immunoreactivity in the olfactory bulb of the rainbow trout (Salmo gairdneri). Brain Res. 490:385-389.

Alonso, J.R., R. Covenas, J. Lara, M. de Leon, R. Arevalo, and J. Aijon (1990) Interspecies differences in the substance $P$ - and vasoactive intestinal polypeptide-like immunoreactivities in the olfactory buib of Salmo gairdneri and Barbud meridionalis. J. Neurosci. Res. 25:103-111

Andres, K.H. (1970) Anatomy and ultrastructure of the olfactory system in fish, amphibia, reptiles, birds and mammals. In G.E.W. Wolstenholme and J. Knight (eds): Taste and Smell in Vertebrates. London: J. and A Churchill, pp. 177-194.

Baker, H., M. Grillot, and F.L. Margolis (1989) Biochemical and immunucytochemical characterization of olfactory marker protein in the rodent central nervous system. J. Comp. Neurol. 285:246-261.

Barber, P.C. (1989) Ulex europeus agglutinin I binds exclusively to primary olfactory neurons in the rat nervous system. Neuroscience 30:1-9.

Bass, A.H. (1981a) Organization of the telencephalon in the channel catfish, Ictalurus punctatus. J. Morph. 169:71-90.

Bass, A.H. (1981b) Olfactory bulb efferents in the channel catfish, Ictalurus punctatus. J. Morph. 169:91-111.

Bazer, G.T., S.O.E. Ebbesson, J.B. Reynolds, and R.P. Bailey (1987) A cobalt-lysine study of primary olfactory projections in king salmon fry (Oncorynchus tshawytscha Walbaum). Cell. Tissue Res. 248:499-503.

Boeckh, J., and V. Boeckh (1979) Threshold and odor specificity of pheromone sensitive neurons in the deutocerebrum of Antherea pernyi and $A$. polyphemus (Saturnidae). J. Comp. Physiol. 132:234-242.

Braford, M.R. Jr., and R.G. Northcutt (1974) Olfactory bulb projections in the bichir, Polypterus. J. Comp. Neurol. 156:165-178.

Cancalon, P. (1985) Influence of temperature on various mechanisms associated with neuronal growth and nerve regeneration. Prog. Neurobiol. 25:27--92.

Capron de Caprona, M.D., H. Munz, B. Fritszsch, and B. Claas (1986) Structure and development of the LHRH-immunoreactive nucleus olfactoretinalis in the cichlid fish brain. In W. Breipohl (ed): Ontogeny of Olfaction. Berlin: Springer-Verlag, pp. 211-223.

Chuah, M.I., and D.R. Zheng (1987) Olfactory marker protein is present in olfactory receptor cells of human fetuses. Neuroscience. 23:363-370.

Demski, L.H. (1984) The evolution of neuroanatomical substrates of reproductive behavior: Sex steroid and LHRH-specific pathways including the terminal nerve. Am. Zool. 24:809-830.

Demski, L.H., and R.G. Northcutt (1983) The terminal nerve: A new chemosensory system in vertebrates? Science 220:435-436.

Doving, K.B., and R. Selset (1980) Behavior patterns in cod released by electrical stimulation of olfactory tract bundlets. Science 207:559-560.

Doving, K.B., R. Selset, and G. Thommesen (1980) Olfactory sensitivity to bile salts in salmonid fishes. Acta Physiol. Scand. 108:123-131.

Droogleever-Fortuyn, J. (1961) Topographical relations in the telencephalon of the sunfish, Eupomotis gibbosus. J. Comp. Neurol. 116:249-263.

Dubois-Dauphin, M., K.B. Doving, and A. Holley (1980) Topographical relation between the olfactory bulb and the olfactory tract in tench (Tinca tinca L.). Chem. Senses 5:159-169.

Duncan, H.J., W.T. Nickell, M.T. Shipley, and R.C. Gesteland (1990) Organization of projections from olfactory epithelium to olfactory bulb in the frog, Rana pipiens. J. Comp. Neurol. 299:299-311.

Ebbesson, S.O.E., G.T. Bazer, and J.A. Jane (1986) Some primary olfactory axons project to the contralateral olfactory bulb in Xenopus laevis. Neurosci. Lett. 65:234-238.

Erickson, J.R., and J. Caprio (1984) The spatial distribution of ciliated and microvillous olfactory receptor neurons in the channel catfish is not matched by a differential specificity to amino acid and bile salt stimuli. Chem. Senses $9: 127-141$.

Evans, R.E., and T.J. Hara (1978) Histochemical localization of phospholipids in the olfactory epithelium of fish. Can J. Zool. 55:776-781.

Finger, T.E. (1975) The distribution of the olfactory tracts in the bullhead catfish, Ictalurus nebulosus. J. Comp. Neurol. 161:125-142.

Finger, T.E. (1988) Organization of chemosensory systems within the brains of bony fishes. In J. Atema, R.R. Fay, A.N. Popper, and W.N. Tavolga 
(eds): Sensory Biology of Aquatic Animals. New York: Springer-Verlag, pp. 339-363.

Fujita, S.C., K. Mori, K. Imamura, and K. Obata (1985) Subclasses of olfactory receptor cells and their segregated central projections demonstrated by a monoclonal antibody. Brain Res. 326:192-196.

Gasser, H.S. (1956) Olfactory nerve fibers. J. Gen. Physiol. 39:473-496.

Greer, C.A., W.B. Stewart, M.H. Teicher, and G.M. Shepherd (1982) Functional development of the olfactory bulb and a unique glomerular complex in the neonatal rat. J. Neurosci. 2:1744-1759.

Hansson, B.S., H. Ljungberg, E. Hallberg, and C. Lofstedt (1992) Functional specialization of olfactory glomeruli in a moth. Science 256:1313-1315.

Hempstead, J.L., and J.1. Morgan (1985a) A panel of monoclonal antibodies to the rat olfactory epithelium. J. Neurosci. 5:438-449.

Hempstead, J.L., and J.I. Morgan (1985b) Monoclonal antibodies reveal novel aspects of the biochemistry and organization of olfactory neurons after unilateral olfactory bulbectomy. J. Neurosci. 5:2382-2387.

Holmgren, N. (1920) Zur Anatomie und Histologie der Vorder- und Zwischenhirns der Knochenfisches. Acta Zool. Stockholm 1:137-315.

Honkanen, T., and P. Ekstrom (1990) An immunocytochemical study of the olfactory projections in the three-spined stickleback, Gasterosteus aculeatus, L. J. Comp. Neurol. 292:65-72.

Ichikawa, M. (1976) Fine structure of the olfactory bulb in the goldfish, Carassius auratus. Brain Res. 115:53--56.

Ito, H. (1973) Normal and experimental studies on synaptic patterns in the carp telencephalon, with special reference to the secondary olfactory termination. J. Hirnforsch, 14:237-253.

Jennes, L., and W.E. Stumpf (1980) LHRH-systems in the brain of the golden hamster. Cell Tissue Res. 209:239-256.

Johnston, J.B. (1898) The olfactory lobes, forebrain, and habenular tracts of acipenser. Zool. Bull. 1:221-241.

Johnston, J.B. (1902) The brain of Acipenser: A contribution to the morphology of the vertebrate brain. Zool. Jahrb., Abt. Anat. Ontogonie 15:59-260.

Kah, O., B. Breton, J.G. Dulka, J. Nunez-Rodriguez, R.E. Peter, A. Corrigan, J.E. Rivier, and W.W. Vale (1986) A reinvestigation of the Gn-RH (gonadotrophin-releasing hormone) systems in the goldfish brain using antibodies to salmon GnRH. Cell Tissue Res. 244:327-337.

Key, B., and P.P. Giorgi (1986a) Soybean agglutinin binding to the olfactory systems of the rat and mouse. Neurosci. Lett. 69:131-136.

Key, B., and P.P. Giorgi (1986b) Selective binding of soybean agglutinin to the olfactory system of Xenopus. Neuroscience 18:507-515.

Kreutzberg, G.W., and G.W. Gross (1977) General morphology and axonal ultrastructure of the olfactory nerve of the pike, Esox lucius. Cell. Tissue Res. 181:443-457.

Margolis, F.L. (1980) A marker protein of the olfactory chemoreceptor neuron. In R.A. Bradshaw and D.A. Schneider (eds): Proteins of the Nervous System. New York: Raven Press, pp. 59-84.

Matsumoto, S.G., and J.G. Hildebrand (1981) Olfactory mechanisms in the moth Manduca sexta: Response characteristics and morphology of central neurons in the antennal lobes. Proc. R. Soc. Lond., B. 213:249277 .

Mesulam, M.M. (1982) Tetramethyl benzidine for horseradish peroxidase neurohistochemistry: A non-carcinogenic blue reaetion-product with superior sensitivity for visualizing neural afferents and efferents. J. Histochem. Cytochem. 26:106-117.

Morgan, J.I. (1988) Monoclonal antibody mapping of the rat olfactory tract. In F.L. Margolis and T.V. Getchell (eds): Molecular Neurobiology of the Olfactory System. New York: Plenum Press, pp. 269-296.

Mori, K., S.C. Fujita, K. Imamura, and K. Obata (1985) Immunohistochemical study of subclasses of olfactory nerve fibers and their projections in the olfactory bulb of the rabbit. J. Comp. Neurol. 242:214-229.

Muller, J.F., and R.E. Marc (1984) Three distinctive morphological classes of receptors in fish olfactory organs. J. Comp. Neurol. 222:482-495.

Munz, H., and B. Claas (1987) The terminal nerve and its development in the teleost fishes. Ann. N.Y. Acad. Sci. 519:50-59.

Munz, H., B. Claas, W.E. Stumpf, and L. Jennes (1982) Centrifugal innervation of the retina by leuteinizing hormone-releasing hormone (LHRH)-immunoreactive telencephalic neurons in teleostean fishes. Cell. Tissue Res. 222:313-323.

Nieuwenhuys, R. (1967) Comparative anatomy of olfactory centers and tracts. Prog. Brain Res. 23:1-64.

Oka, Y. (1983) Golgi, electron microscopic and combined Golgi-electron microscopic studies of the mitral cells in the goldfish olfactory bulb. Neuroscience 8.723-742.
Pfeiffer, W. (1963) The morphology of the olfactory organ of the pacific salmon (Oncorhyncus). Can. J. Zool. 41:1233-1236.

Rhein, L.D., R.H. Cagan, P.M. Orkand, and M.K. Dolack (1981) Surface specializations of the olfactory epithelium of rainbow trout, Salmo gairdneri. Tissue Cell 13:577-587.

Riddle, D.R., and B. Oakley (1991) Evaluation of the organization of the primary olfactory projection in rainbow trout. J. Neurosci. 11:37523762 .

Rowley, J.C., D.T. Moran, and B.W. Jafek (1989) Peroxidase backfills suggest the mammalian olfactory epithelium contains a second morphologically distinct class of bipolar sensory neuron: The microvillar cell. Brain Res. 502:387-400.

Satou, M. (1990) Synaptic organization, local neuronal circuitry, and functional segregation of the teleost olfactory bulb. Prog. Neurobiol 34:115-142.

Satou, M., M. Ichikawa, K. Ueda, and S.F. Takagi (1979) Topographical relation between olfactory bulb and olfactory tract in the carp. Brain Res. 173:142-146.

Scalia, F, and S.O.E. Ebbesson (1971) The central projections of the olfactory bulh in a teleost (Gymnothorax funebris). Brain Behav. Evol 4:376-399.

Schwanzel-Fukuda, M., and A.J. Silverman (1980) The nervus terminalis system of the guinea pig: A luteinizing hormone-releasing hormone (LHRH) neuronal system. J. Comp. Neurol, 191:213-225.

Schwanzel-Fukuda, M., M.S. Garcia, J.J. Morell, and D.W. Pfaff (1987) Distribution of luteinizing hormone-releasing hormone in the nervus terminalis and brain of the mouse detected by immunocytochemistry. $J$ Comp. Neurol. 255:231-244.

Schwob, J.E., and D.I. Gottlieb (1986) The primary olfactory projection has two chemically distinct zones. J. Neurosci. 6:3393-3404.

Sheldon, R.E. (1912) The olfactory tracts and centers in teleosts. J. Comp. Neurol. 22:177-338.

Shinoda, K., Y. Shiotani, and Y. Osawa (1989) "Necklace olfactory glomeruli" form unique components of the rat primary olfactory system. J. Comp. Neurol. 284:362-373.

Sorenesen, P.W., T.J. Hara, N.E. Stacey, and F.W. Goetz (1988) F prostaglandins function as potent olfactory stimulants that comprise the postovulatory female sex pheromone in goldfish. Biol. Reprod. 39:1039-1050.

Stacey, N.E., and A.L. Kyle (1983) Effects of olfactory tract lesions on sexual and feeding behavior of fish. Physiol. Behav. 30:621-628.

Stell, W.K., and S.E. Walker (1987) Functional-anatomical studies on the terminal nerve projection to the retina of bony fishes. Ann. N.Y. Acad. Sci. 519:80-96.

Stell, W.K., s.E. Walker, K.s. Chohan, and A.K. Ball (1984) The goldfish nervus terminalis: An LHRH- and FMRF-amide-immunoreactive olfactoretinal pathway. Proc. Natl. Acad. Sci. U.S.A. 81:940-944.

Story, R.H. (1964) The olfactory bulbar formation and related nuclei of the paddlefish (Polyodon spathula). J. Comp. Neurol. 123:285-298.

Szabo, T., S. Blahser, J.P. Denizot, and M. Ravaille-Veron (1991) Extrabulbar primary olfactory projection in teleost fishes. Comptes Redus De L Acadamie Des Sciences-Serie Iii, Sciences De La Vie. 312:555-560.

Teicher, M.H., W.B. Stewart, J.S. Kauer, and G.M. Shepherd (1980) Suckling pheromone stimulation of a modified glomerular region in the developing rat olfactory bulb revealed by the 2-deoxyglucose method. Brain Res. 194:530-535.

Thommesen, G. (1978) The spatial distribution of odor induced potentials in the olfactory bulb of char and trout (Salmonidae). Acta. Physiol. Scand. 102:205-217.

Thommesen, G. (1982) Specificity and distribution of receptor cells in the olfactory mucosa of the char (Salmo alpinus). Acta. Physiol. Scand. 115:47-56.

Thommesen, G. (1983) Morphology, distribution, and specificity of olfactory receptor cells in salmonid fishes. Acta. Physiol. Scand. 117:241-250.

von Bartheld, C., B. Claas, H. Munz, and D.L. Meyer (1988) Primary olfactory projections and the nervus terminalis in the African lungfish: Implications for the phylogeny of cranial nerves. Am. J. Anat. 182:325334.

Wirsig, C.R., and T.V. Getchell (1986) Amphibian terminal nerve: Distribution revealed by LHRH and AChR markers. Brain Res. 385:10-21.

Yamamoto, M. (1982) Comparative morphology of peripheral olfactory organ in teleosts. In T.J. Hara (ed): Chemoreception in Fishes. Amsterdam: Elsevier, pp. 39-59.

Zielinski, B., and T.J. Hara (1988) Morphological and physiological develop ment of olfactory receptor cells in rainbow trout (Salmo gairdneri) embryos. J. Comp. Neurol. 271:300-311. 